\title{
Preliminary Survey of Microorganisms Associated with Some Insects in Puerto Rico ${ }^{1}$
}

\author{
Goro Kuno ${ }^{2}$
}

\begin{abstract}
Many bacteria, fungi and several species of nematodes were isolated during a preliminary investigation of microorganisms associated with some insects of Puerto Rico. Although most of the organisms did not prove to be parasitic, a few fungi, notably Metarrhizium anisopliae and Entomophthora virulenta, were found highly pathogenic under laboratory conditions. Several protozoa belonging to Microsporida were found in Aedes mediovitlatus, Anopheles grabhamii, Culex secutor, and Diatraea saccharalis for the first time.
\end{abstract}

\section{INTRODUCTION}

The symbioses between microorganisms and insects constitute an important area of entomological research. One branch of such studies, insect pathology, has become extremely important in agriculture and public health because of the potential of controlling insect pests by means of artificially-manipulated epizootics through use of pathogens $(1,12)$.

Before applying microbial agents in a locality where extensive, artificial dissemination of pathogens is contemplated, effective pathogens indigenous to the area should be surveyed, isolated and identified. A majority of effective pathogenic species available today were isolated originally in the temperate regions of the world. However, many of these have demonstrated to lose their viability or virulence-viruses and bacteria under ultra-violet irradiation and higher temperature; fungi under dry environmental conditions. Although those disadvantages be partially alleviated by improvement in formulation; e.g., use of protectant, encapsulation, etc., it still is desirable to exploit both foreign and indigenous strains or species of pathogens which may be better suited to a particular climate and other environmental situations. Furthermore, entomogenous pathogens isolated from insect species in temperate regions may not necessarily be effective against tropical insects, as many pathogens are host specific.

1 Manuscript submitted to Editorial Board April 23, 1974.

2 Assistant Professor of Biology, Faculty of Arts and Sciences, Mayagüez Campus, University of Puerto Rico, Mayagüez, P.R. Acknowledgements are due to Drs. C. P. Kurtzman, Northern Utilization Research and Development Division, U.S. Department of Agriculture, Peoria, nlinois; R. Lichtwardt, University of Kansas, Lawrence, Kansas; D. M. MacLeod, Canada Dept. Forestry, Sault Ste. Marie, Ontario, Canada; W. R. Nickle, USDA, Beltsville, Maryland; and W. Snyder, University of California, Berkeley, California, for their generous help in the identification of the microorganisms. 
Although Puerto Rico is by no means undisturbed in terms of microbial flora $(4,7,8,13)$, it still is worthwhile to continue searching for effective pathogens here. This is a preliminary report on the survey of the microorganisms and neomatodes found associated with some selected insects, with emphasis on their pathogenicity.

\section{MATERIALS AND METHODS}

\section{COLLECTION AND EXAMINATION OF INSECT SPECIMENS}

Dead or ailing specimens collected in the field were each put in separate specimen vials and given an accession number. External signs of diseases were recorded. Specimens then were dissected and both tissues and samples of hemolymph were examined microscopically.

\section{PATHOGENICITY TEST OF BACTERIA}

Bacteria were isolated, then cultured in suitable media including nutrient agar, nutrient broth, and Bacto-AC medium. In testing for pathogenicity, living specimens were used of the same insect species from which the bacteria were isolated initially. Experimental larvae (starved for 24 hours prior to inoculation) were fed food contaminated with the suspension of each bacterial isolate and then reared at $28^{\circ} \mathrm{C}$. Whenever mortality was recorded, the dead larvae were dissected and an attempt was made to recover the bacteria used as inocula. Unless stated otherwise, methods used for inoculating food, for rearing and observing treated larvae, and for recovery of pathogens were identical.

\section{PATHOGENICITY TEST OF FUNGI}

Each fungus was cultured in one of the suitable media including Sabouraud dextrose agar, Sabouraud maltose plus yeast extract agar, Czapek medium, yeast culture medium, and potato dextrose agar. Larvae were placed on the sporulating culture of each isolate in petri dishes for 24 hours, and reared thereafter with sufficient amount of food. In case of scale insects, each fungal suspension was sprayed over the surface of chironja $a^{3}$ fruits infested with armored nymphs and/or gravid adult females of Selenaspidus articulatus according to the method of Kuno and Colón (8).

\section{PATHOGENICITY TEST OF NEMATODES}

The live test insects were fed food contaminated with crude homogenate of dead specimens containing live nematodes. Special care was taken to facilitate possible cutaneous infection.

3 Chironja is a new citrus fruit discovered in Puerto Rico. 


\section{PATHOGENICITY TEST OF PROTOZOA}

One group of test insects was fed food contaminated with a homogenate of dead insects. Another group was injected aliquots (2.4 microliters) of protozoa suspension prepared after Ficoll density gradient (10 to 35 percent) centrifugation (9) of the homogenate containing spores. Mosquitoes were infected by contaminating the culture media of the larvae with a homogenate of specimens killed by protozoan infection.

PATHOGENICITY TEST OF THE HOMOGENATE DERIVED FROM THE SPECIMENS SUSPECTED OF HAVING VIRAL DISEASES

One group of experimental insects were fed food contaminated with a homogenate of dead insects. Another group was intrahemocoelically injected aliquots (2.4 microliters) of the suspected fractions after $0.5 \mathrm{ml}$ of the homogenate was laid on $4.5 \mathrm{ml}$ of discontinuous sucrose density gradient (15 to 80 percent) and centrifuged (with Beckman L2-65 ultracentrifuge) at a force of $112,000 \times \mathrm{g}$ for 3 hours.

\section{RESULTS AND DISCUSSION}

The following tabulation shows the results of the study:

\begin{tabular}{|c|c|c|}
\hline Insect & $\begin{array}{l}\text { Associated microorganisms and/or } \\
\text { nematodes }\end{array}$ & $\begin{array}{c}\text { Nature of } \\
\text { association? }\end{array}$ \\
\hline \multicolumn{3}{|l|}{ COLEOPTERA } \\
\hline Diaprepes abbreviatus & $\begin{array}{l}\text { B. Micrococcus sp. } \\
\text { Serratia sp. }\end{array}$ & $\begin{array}{l}\mathbf{S} \\
\mathbf{S}\end{array}$ \\
\hline Melamasius hemipterus & $\begin{array}{l}\text { B. Aerobacter sp. } \\
\text { N. unidentified }\end{array}$ & $\begin{array}{l}\mathbf{U} \\
\mathbf{U}\end{array}$ \\
\hline Phyllophaga portoricensis & $\begin{array}{l}\text { B. Bacillus sp. } \\
\text { P. gregarine }\end{array}$ & $\begin{array}{l}\text { U. } \\
\text { U }\end{array}$ \\
\hline \multicolumn{3}{|l|}{ DIPTERA } \\
\hline Aedes aegypti & $\begin{array}{l}\text { B. Aerobacter sp. } \\
\text { Micrococcus sp. } \\
\text { Bacillus sp. } \\
\text { F. Amoebidium parasiticum } \\
\text { P. gregarine } \\
\text { Thelohania sp. }\end{array}$ & $\begin{array}{l}\text { S } \\
\text { S } \\
\text { S } \\
\text { C } \\
\text { U } \\
\text { PIC }\end{array}$ \\
\hline A. medioviltatus & P. Microsporida & $\mathbf{U}$ \\
\hline Anopheles grabhamii & P. Thelohania sp. & PIC \\
\hline Culex quinquefasciatus & P. Microsporida & $\mathbf{U}$ \\
\hline Culex secutor & P. Microsporida & PIC \\
\hline \multicolumn{3}{|l|}{ HEMIPTERA-HOMOPTERA } \\
\hline Bemisia tabaci & F. Spicaria rileyi & $\mathbf{U}$ \\
\hline Myzus persicae & F. Entomophthora virulenta & $\mathbf{P}$ \\
\hline Nezara viridula & F. Aspergillus spp. & $\mathbf{S}$ \\
\hline Saccharicoccus sacchari & F. Aspergillus sp. & $\mathbf{U}$ \\
\hline
\end{tabular}




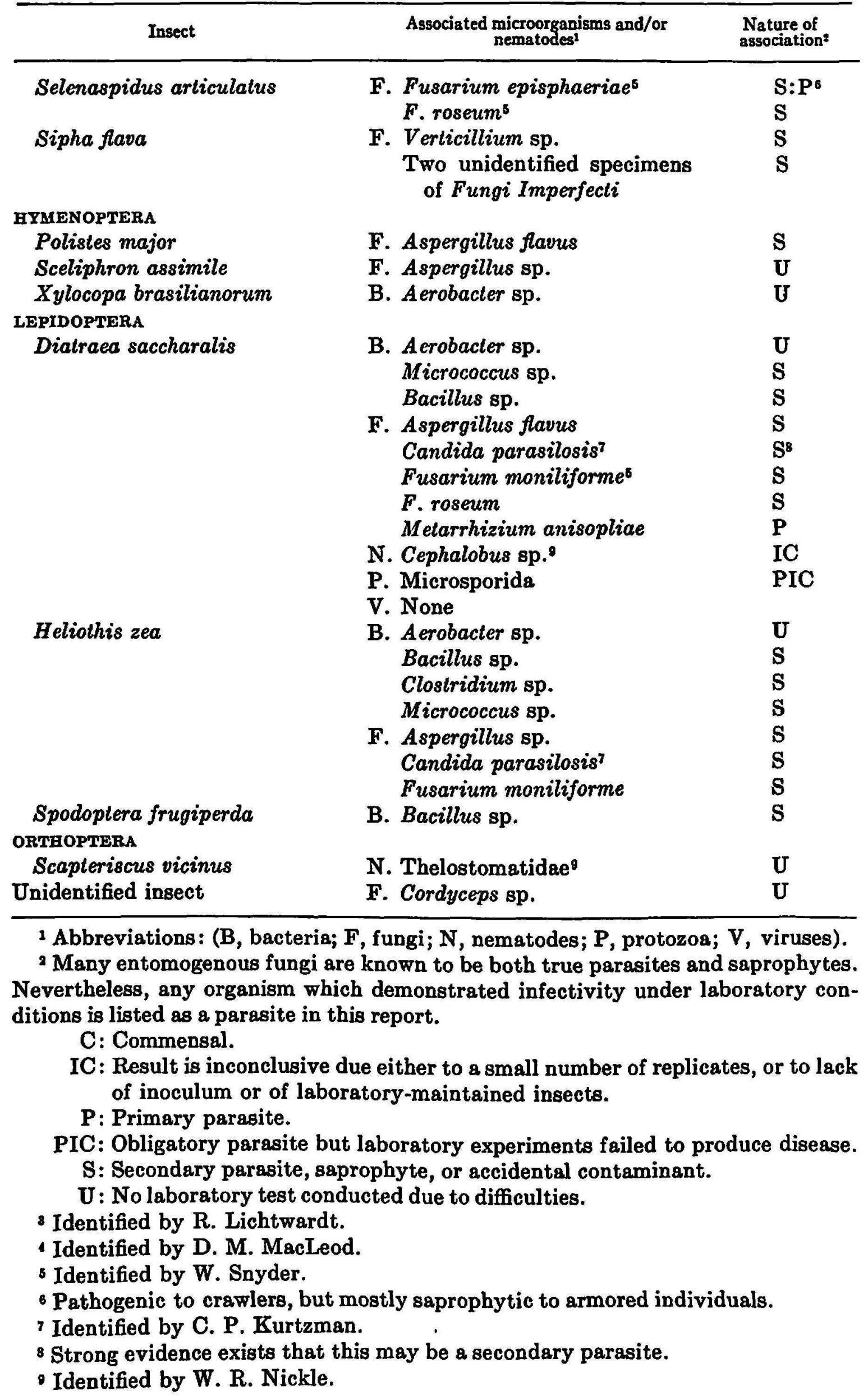


Extensive lists of microorganisms associated with insects of Puerto Rico were published by Johnston (5) and Charles (2), who dealt exclusively with the fungi.

Monographs such as these are still useful but it has become necessary in recent years to reappraise relationships between insects and their associated microorganisms. Mere presence of microorganisms in or on dead insects was reported on many occasions in the early days as parasitism without the proof of performance by pathogenicity tests under the controlled environment of the laboratory. It now is extremely important to analyze the pathogenicity and/or virulence of microorganisms associated with insects from the standpoint of microbial control of economic insect species. The need for such information was stressed by Gustafsson (4) and Kuno and Colón (8) who reported the ineffectiveness of a fungus previously thought to be an effective agent for the biological control of a number of insect species.

The need for more extensive surveys is indicated as many fungi listed by Charles (2) have not been isolated thus far in this study. As shown by this study, the strong virulence of Metarrhizium anisopliae to Diatraea saccharalis and other insects $(11,13)$ confirms the effectiveness of this fungus as a natural control agent. Entomophthora fungi cited frequently as effective entomogenous fungi also were reported earlier by Kevorkian (6). However, a caution must be given in considering the artificial dissemination of Entomophthora fungi as several have been implicated in cutaneous infection of some mammals.

One of the interesting results of this preliminary survey is the discovery of Microsporidan parasites in several mosquito species and the sugarcane borer, $D$. saccharalis. Although Nosema aedis (7) and others have been reported from Aedes aegypti, this is the first report so far as the author knows of Microsporidan parasites from Aedes mediovittatus, Anopheles grabhamii, Culex secutor, and Diatraea saccharalis. No definite evidence of viral pathogens was found but a strong possibility exists that they will be isolated in the future as a granulosis virus (10) and an unidentified virus (3) were reported from $D$. saccharalis in Louisiana and in Guadeloupe, respectively.

\section{RESUMEN}

Durante la primera fase de la investigación sobre los microorganismos asociados con varios insectos de Puerto Rico, se aislaron muchas bacterias y hongos, así como varias especies de nematodos. Aunque la mayoría de dichos microorganismos probaron no ser parasíticos, se encontró que algunos hongos, particularmente Metarrhizium anisopliae y Entomophthora virulenta, eran muy patogénicos bajo las condiciones prevalecientes en el laboratorio. Además, varios parásitos protozoarios pertenecientes a los microspóridos, fueron descubiertos por primera vez en Aedes medioviltatus, Anopheles grabhamii, Culex secutor, y Diatraea saccharalis. 


\section{LITERATURE CITED}

1. Burges, H. D., and Hussey, N. W., Microbial Control of Insects and Mites, Academic Press, New York, N.Y. 1971.

2. Charles, V. K., A preliminary check list of the entomogenous fungi of North America, Bur. Pl Ind., USDA Insect Pest Survey Bull. 21 (Suppl. to No. 9): 707-85, 1941.

3. Galichet, P. F., Personal communication, 1972.

4. Gustafsson, M., Microbial control of aphids and scale insects, In: "Microbial Control of Insects and Mites", H. D. Burges and N. W. Hussey, eds. Academic Press, New York, N.Y., pp. 375-84, 1971.

5. Johnston, J. R., The entomogenous fungi of Porto Rico. Bull. 10, Board of Commissioners of Agriculture, Rio Piedras, P.R., pp. 1-33, 1915.

6. Kevorkian, A. G., Studies in the Entomophthoraceae. I. Observations on the genus Conidiobolus. J. Agr. Univ. P.R. 21 : 191-200, 1937.

7. Kudo, R. R., Studies on Microsporidia parasitic in mosquitoes. VIII. On Aedes aegypti of Porto Rico, Arch. Protistenk 69: 23-38, 1930.

8. Kuno, G., and Colón Ferrer, M., Pathogenicity of two Fusarium fungi to an armored scale insect, Selenaspidus articulatus, J. Invertebr. Pathol., 22: 47374, 1973.

9. Pharmacia Fine Chemicals, About Ficoll. Separation News, January, 1973.

10. Steinhaus, E. A., and Marsh, G. A., Report of diagnosis of diseased insects, 19511961. Hilgardia 33(9): 349-490, 1962.

11. Stevenson, J. A., The green muscardine fungus in Porto Rico (Metarrhizium anisopliae (Metsch.) Sorokin). J. Dept. Agr. P.R. 2(1): 19-32, 1918.

12. Van der Laan, P. A., Insect Pathology and Microbial Control, North-Holland Publishing Co., Amsterdam, Holland, 1967.

13. Wolcott, G. N., Experiences with entomogenous fungi in Puerto Rico, Agr. Exp. Sta., Univ. P.R. Bull, 130, Río Piedras, P.R., 1955. 